\title{
PENINGKATAN KEMAMPUAN GURU DALAM PEMBUATAN \\ KELENGKAPAN PERANGKAT PEMBELAJARAN MELALUI SUPERVISI KEPALA SEKOLAH
}

\author{
Sukirman \\ SDN Badurame I Turi \\ Kabupaten Lamongan
}

\begin{abstract}
This research aimed to improve the ability of teachers in making the completeness of learning devices. This action research is done by following the main flow: initial reflection, planning, action execution, observation, reflection, and redesign. The results showed that classroom supervision activities can improve the ability of teachers in the ability of teachers in making the completeness of learning devices and managing the class administration in Badurame I State Elementary School, Turi sub-district, Lamongan.
\end{abstract}

Keywords: improvement, teacher ability, learning tool, supervision

Abstrak: Penelitian ini dilakukan bertujuan untuk meningkatkan kemampuan guru dalam pembuatan kelengkapan perangkat pembelajaran. Penelitian tindakan ini dilakukan dengan mengikuti alur pokok: refleksi awal, perencanaan, pelaksanaan tindakan, pengamatan, refleksi, dan perancangan ulang. Hasil penelitian menunjukkan bahwa kegiatan supervisi kelas dapat meningkatkan kemampuan guru dalam kemampuan guru dalam pembuatan kelengkapan perangkat pembelajaran dan mengelola administrasi kelas di Sekolah Dasar Negeri Badurame I, kecamatan Turi, Lamongan.

Kata kunci: peningkatan, kemampuan guru, perangkat pembelajaran, supervisi

\section{PENDAHULUAN}

Selama ini bukti fisik sebagai pendukung kelancaran kegiatan pembelajaran guru (administrasi kelas), respon dikalangan guru masih kurang. Kenyataan ini banyak hal yang menjadi pertimbangan utamanya bagi guruitu sendiri, termasuk masih rendahnya frekuensi kepengawasan dan binaan dari pihak yang berkompeten.

Untuk mewujudkan agar kelengkapan administrasi kelas itu benarbenar memperoleh respon, maka perlu adanya binaan intensif sehingga kinerja guru bisa maksimal terutama pemahaman jenis format serta pola pengerjaannya. Pembinaan yang harus diterima guru kelas sangatlah penting dan merupakan kebutuhan guna penyeimbang kinerja antara supervisor maupun guru yang bersangkutan. Jika hal ini tidak tercipta dengan baik atau terprogram secara sistemik maka semua itu hanyalah berupa wacana belaka. Fenomena telah dipropagandakan oleh semua kalangan akademisi termasuk tenaga profesional (guru) perlunya meningkatkan mutu pendidikan dan mutu lulusan, salah satu 
dari sejumlah dimensi sistem pendidikan berupa administrasi kelas harus diberdayakan.

Sejalan dengan proses menuju lahirnya kualitas hasil belajar siswa, maka upaya peningkatan kualitas pendidikan dan komitmen Kepala Sekolah dalam peran-nya harus realistis. Kepala sekolah dalam perannya selaku administrator, supervisor di lingkungan sekolah yang dipimpinnya. Supervisi sebagai tanggung jawab dan kewajiban rutinitas yang harus dilakukan untuk mengetahui adanya kelengkapan administrasi tertulis yang dibuat oleh para guru sebagai pedoman dalam kegiatan proses belajar mengajar di kelas.

Seorang guru dalam melaksanakan tugas harus konsisten membuat kelengkapan berupa sarana dan prasarana penunjang yang digunakan sebagai pedoman dalam menyampaikan materi pembelajaran kepada siswa didik di kelas. Karena dengan kelengkapan administrasi tersebut, seorang guru dalam melakukan kegiatan belajar mengajar berjalan dengan efektif dan tujuan yang diharapkan dapat tercapai secara positif. Untuk mewujudkan kondisi proses pembelajaran yang diimbangi dengan adanya kelengkapan administrasi itu agar lebih efektif dibutuhkan sarana kontrol melalui supervisi kelas. Dengan dilaksanakannya supervisi ini dimaksudkan memiliki pengaruh positif terhadap aktivitas guru dalam melaksanakan proses kegiatan belajar mengajar di kelas.

Menurut uraian di atas, untuk menciptakan kondisi pembelajaran yang baik diperlukan jalinan positif antara Kepala Sekolah selaku supervisor dan guru yang disupervisi baik kelengkapan administrasi kelas maupun dalam kegiatan proses belajar mengajarnya. Hal ini dimaksudkan bila yang mempunyai peran baik kepala sekolah maupun guru tidak memenuhi tugas dan tanggung jawabnnya, maka tujuan yang diharapkan tidak akan tercapai.

Kenyataan dilapangan sering terjadi ketimpangan dalam penanganan administrasi dan penekanan pada proses belajar mengajar. Guru saring beranggapan bahwa yang penting mereka dapat melaksanakan proses belajar mengajar dengan baik sudah dianggap cukup, sedangkan dukungan data berupa administrasi kurang dapat perhatian.

Sebagaimana pernyataan di atas bahwa untuk meningkatkan kualitas guru dalam melaksanakan program pembelajaran tidak cukup dengan pemberian penjelasan-penjelasan yang bersifat pengetahuan, melainkan harus disertai contoh-contoh proses pembelajaran berikut skenario model rencana pembelajaran hingga pelaksanaan evaluasi. Kepala sekolah memandang sangat penting untuk memberikan informasi sekaligus monitoring terhadap kinerja guru kelas secara independen. Peneliti ketika awal melaksanakan dinas pada tugas baru menjadi pimpinan lembaga melakukan pengamatan fisik dan non-fisik utamanya terhadap eksistensi guru yang ada di SDN Badurame I Turi. Ketika itu mencoba menangkap dan menerjemahkan karakter pendidik tentang kesiapan dalam melaksanakan tugas pokok dan funsinya. Melalui kegiatan awal mengiventarisir kelengkapan administrasi kelas rata-rata baru mencapai 62,25\%, sementara target minimal kelengkapan mengajar harus pada tingkatan rata - rata $75 \%$.

Berdasarkan kenyataan tersebut peneliti berasumsi dan bersikap melakukan pengadaan administrasi kelas yang dilanjutkan kegiatan sosialisasi baik melalui rapat rutin setiap bulan maupun ketika dalam keadaan istirahat. Agar suasana kinerja guru dapat maksimal dan pencapaian ketuntasan hasil belajar siswa tercapai harus ada perubahan.Sebagai alternatif pemecahannya maka peneliti 
selaku kepala sekolah menggunakan perannya melalui kegiatan penelitian dengan melakukan 'Penelitian Tindakan' (PT) atau 'Penelitian Tindakan Supervisi' (PTS) dengan menetapkan judul penelitian "Peningkatan Kemampuan Guru dalam Pembuatan Kelengkapan Perangkat Pembelajaran Melalui Supervisi Kepala Sekolah".

Penelitian ini dilakukan bertujuan untuk meningkatkan kemampuan guru dalam pembuatan kelengkapan perangkat pembelajaran.

\section{METODE PENELITIAN}

Penelitian ini menggunakan subjek pada guru Sekolah Dasar Negeri Badurame I,kecamatan Turi, kabupaten Lamongan sebanyak 7 (tujuh) orang guru. Alokasi waktu yang digunakan dalam penelitian ini adalah 2 bulan secara berturut-turut dari bulan Oktober 2012 sampai dengan bulan Desember 2012 bertempat di Sekolah Dasar Negeri Badurame I, kecamatan Turi, kabupaten Lamongan.

Penelitian ini menggunakan rancangan Penelitian Tindakan (PT). Penelitian Tindakan dipilih pada penelitian ini karena penulis selaku kepala sekolah berupaya meningkatkan kemampuan guru dalam pengelolaan serta pembuatan perangkat pembelajaran berupa kelengkapan administrasi kelas. Kegiatan penelitian ini dilakukan dengan mengikuti alur pokok: refleksi awal, perencanaan, pelaksanaan tindakan, pengamatan, refleksi dan perancangan ulang.

\section{HASIL PENELITIAN DAN PEMBAHASAN}

Siklus 1

\section{Dasar-Dasar Pelaksanaan Kegiatan Supervisi}

Pemberian informasi kedinasan kepada guru melalui rapat sekolah tentang kinerja guru menyangkut masalah-masalah ketatalaksanaan yang mendukung adanya kemampuan mengelola administrasi kelas beserta kelengkapan lain sebagai pendukung efektivitas kegiatan pembelajaran di kelas, khususnya pada tugas pokok guru masing-masing kelas. Kepala Sekolah dalam hal ini selaku peneliti menyarankan pada rapat sebagai berikut :

a. Memberikan kebebasan kepada guru untuk melengkapi kebutuhan kelas menurut ketentuan pada buku pedoman yang berlaku.

b. Memberikan kesempatan kepada guru untuk memahami masing-masing karakteristik pengelolaan administrasi kelas.

c. Memberikan kebebasan guru untuk bertanya sesama teman guru sebagai mitra kerja tentang segala hal yang belum dipahaminya.

d. Memberikan kesempatan kepada guru untuk mengembangkan ekspresinya dalam pengelolaan administrasi kelas yang telah dibuatnya.

e. Memberikan kesempatan kepada guru untuk memilih waktu yang tepat untuk melakukan penyempurnaan administrasinya.

Langkah awal ini terbukti memberikan dampak positif guru terhadap kemampuan pengelolaan administrasi kelas. Dengan proses tindakan pengelolaan administrasi kelas yang efektif guru merasa lebih senang mengerjakan tugas pokok yang dihadapi dan merasakan kebebasan di dalam mengelola administrasi kelas.

Guru dalam tugasnya membuat kelengkapan administrasi setelah melaksanakan kegiatan pembelajaran sangat menyenangkan dan dapat meningkatkan kemampuan memahami ragam administrasi kelas.

Kepala Sekolah juga memberikan kesempatan secara individu untuk menanyakan segala sesuatu yang belum dipahaminya.Beberapa masalah yang 
tidak dapat ditemukan dalam buku pedoman administrasi dijelaskan kepala sekolah melalui kelakar dan rapat rutin. Sedang pertanyaan-pertanyaan lain yang bersifat individual dijawab pula secara individu, sebaliknya kepala sekolah juga sangat demokratis dalam penentuan sikap baik dalam rapat maupun situasi lain. Beberapa hal yang dicatat pada pertemuan pertama ini, antara lain :

a) Waktu yang digunakan guru belum maksimal.

b) Kurang telitinya guru dalam mengisi format-format atau kolom administrasi yang tersedia.

Kemampuan guru kelas mulai muncul, karena guru menyadari perlunya tertib administrasi sebagai pendukung kinerja sehari-hari di kelas. Guru merasa ada kemudahan dalam mengelola administrasi karena kepala sekolah selalu memberikan bimbingan dan pengarahan kepada guru juga bila menemui kesulitan dapat ditemukan di buku sumber atau buku pedoman. Para guru dengan asyik berusaha mencari dan menemukan sendiri cara-cara pengelolaan administrasi kelas berikut pembuatannya.

Tugas pokok guru menyusun kelengkapan administrasi kelas, 1) Program Semester, 2) Persiapan Mengajar, 3) Kisi-kisi soal ulangan, 4) Kumpulan soal ulangan,

5) Hasil Evaluasi-Daftar Nilai Siswa, 6) Analisis Hasil Evaluasi Belajar, 7) Program Perbaikan dan Pengayaan, 8) Program Bimbingan dan Konseling, 9) Data Kelas, 10). Bank Data, 11). Buku Supervisi, 12). Buku Tamu, 13). Buku Penerimaan Raport, 14). Buku Mutasi, 15). Buku Kas, 16). Buku Iventaris, 17). Buku Notulen Rapat, 18). Visualisasi Data terdiri dari, (a) Papan Absensi, (b) Jadwal Pelajaran, (c) Daftar Piket, (d) Iventarisasi Kelas, (e) Organisasi Kelas, (f) Denah Tempat Duduk Siswa (kelas), (g) Tata Tertib Kelas, (h) Struktur Paguyuban Kelas. Selanjutnya untuk menentukan adanya upaya peningkatan kemampuan guru mengelola administrasi kelas, peneliti menetapkan kriteria penskoran sbb:

Tabel 1: Daftar Pedoman/Kriteria Penskoran

\begin{tabular}{|c|l|c|}
\hline No & \multicolumn{1}{|c|}{ Kriterian Penilaian } & Skor \\
\hline 1 & Pengelolaan Administrasi sangat baik & 100 \\
\hline 2 & Pengelolaan Administrasi baik & 80 \\
\hline 3 & Pengelolaan Administrasi cukup & 60 \\
\hline 4 & Pengelolaan Administrasi kurang & 40 \\
\hline 5 & Pengelolaan Administrasi sangat kurang & 20 \\
\hline
\end{tabular}

Berikut ini kemampuan guru dalam melakukan pengelolaan administrasi kelas melalui data aktivitas kinerja yang menunjukkan peningkatan kemampuan guru pada pengelolaan administrasi kelas pada siklus pertama melalui tindakan supervisi kepala sekolah pertama hasilnya 68,57.

Berdasarkan data tersebut dapat disimpulkan bahwa kemampuan guru dalam mengelola administrasi kelas jika mencapai maksimal ( sangat baik) akan memperoleh skor 700 dari 7 (tujuh) orang guru. Sementara hasil penelitian pada tindakan pertama kegiatan supervisi kelas baru mencapai rata-rata 68,57 persen atau tingkat keberhasilannya masih jauh dibawah $75 \%$, hal ini menunjukkan para guru SDN Badurame I, kecamatan Turi kemampuan yang dicapai pada kategori cukup.

Pada tahap berikutnya kepala sekolah mengajak para guru untuk berupaya meningkatkan kelengkapan dan pengelolaan administrasi kelas yang lebih baik. 
Guru yang merasa tugasnya masih kurang sempurna harus menyempurnakan hingga mencapai hasil maksimal. Hal ini dimaksudkan agar pelaksanaan kegiatan pembelajaran berjalan normal dan masing-masing guru akan memiliki kompetensi pada bidangnya secara professional. Sebaliknya jika kekurangan itu tidak segera diperbaiki akan berdampak ini pada kegiatan-kegiatan selanjutnya.

Data kinerja guru yang menunjukkan kemampuan mengelola administrasi kelas pada siklus pertama tindakan supervisi kedua saat pembahasan pembuatan administrasi kelas bagi guru sekolah Dasar Negeri Badurame I, KecamatanTuri menunjukkan hasil 71,42.

Dari data tersebut terlihat adanya perubahan dari data pada tindakan supervisi pertama tercatat 68,57 persen, pada skor tindakan supervisi kedua menjadi 71,42 persen. Hal ini dapat disimpulkan bahwa frekuensi supervisi harus berlangsung secara inten dan terprogram guna upaya peningkatan kemampuan guru dalam mengelola administrasinya semakin baik dan sempurna.

Pada akhir tahap ini kepala sekolah memberikan penilaian mengenai hasil kinerja guru. Hal ini dimaksudkan untuk lebih memberikan semangat kepada guru bahwa semakin sempurna dan teliti dalam mengerjakan administrasi kelas akan mendapat penghargaan (nilai) yang lebih baik pada DP3-nya.

Pada akhir kegiatan, kepala sekolah dan guru berdiskusi berdasar pada beberapa kesimpulan kegiatan dan memberikan alternative guna peningkatan kemampuan pengelolaan administrasi kelas selanjutnya. Sebelum kegiatan supervisi lanjutan berlangsung kepala sekolah juga memberikan tugas agar guru mempelajari pedoman pengelolaan administrasi berikut penerapan di kelas masing-masing guru.

\section{Hasil Tindakan Supervisi pada Siklus Ke Satu}

Berdasarkan hasil tindakan supervisi yang telah dilaksanakan dua kali terhadap masing-masing guru menunjukkan bahwa telah ada peningkatan kemampuan guru dalam pengelolaan administrasi kelas.

Dari 7 (tujuh) guru telah menunjukkan kemampuannya mengelola administrasi kelas masing-masing. Selama dilakukannya pembinaan dan tindakan supervisi kelas masing-masing guru kelas dua kali oleh kepala sekolah hasilnya dapat diketahui pada tabel berikut:

Tabel 2 : Hasil Penelitian Dua Kali Supervisi pada Siklus Pertama

\begin{tabular}{|c|c|c|c|c|c|c|}
\hline \multirow{2}{*}{ No } & $\begin{array}{c}\text { Aspek } \\
\text { Yang } \\
\text { dinilai }\end{array}$ & $\begin{array}{c}\text { Awal } \\
(0)\end{array}$ & $\begin{array}{c}\text { Supervisi } \\
(\mathrm{I})\end{array}$ & $\begin{array}{c}\text { Supervisi } \\
(2)\end{array}$ & $\begin{array}{c}\text { Jumlah } \\
(+)\end{array}$ & Peningkatan \\
\hline 1 & 1 & 00 & 100 & 100 & 200 & Nihil \\
\hline 2 & 2 & 160 & 160 & 240 & 560 & +80 \\
\hline 3 & 3 & 120 & 180 & 120 & 420 & Nihil \\
\hline 4 & 4 & 120 & 40 & 40 & 200 & -40 \\
\hline 5 & 5 & 00 & 00 & 00 & 00 & Nihil \\
\hline- & Jumlah & 400 & 480 & 500 & 1380 & - \\
\hline- & $\begin{array}{c}\text { Rata- } \\
\text { rata }\end{array}$ & 57,14 & 68,57 & 71,42 & - & - \\
\hline
\end{tabular}


Berawal dari data tersebut para guru diberikan pembinaan oleh kepala sekolah dan dilakukan pengawasan secara intensif oleh kepala sekolah. Secara bertahap kepala sekolah melakukan supervisi melalui siklussiklus. Siklus pertama dilakukan 2 (dua) kali supervisi, tindakan pertama diperoleh data rata-rata skor guru68,57 atau 69 persen. Skor tersebut jika dibandingkan dengan skor sebelumnya terdapat peningkatan 71,42 atau 71 persen.

Kemudian pada tahap ke dua diperoleh data berupa skor rata-rata 68,57 atau 69 persen. Dengan demikian pelaksanaan tindakan penelitian ini mempunyai dampak positif terhadap peningkatan kemampuan guru mengelola administrasi kelas, dan perlu pengembangan lebih lebih lanjut dengan penyempurnaan yang berarti.

\section{Rekomendasi Siklus Pertama}

Walaupun pada siklus pertama ini baik proses maupun hasil menunjukkan hasil yang cukup, tetapi beberapa catatan penyempurnaan masih perlu dilakukan, antara lain sebagai berikut :

1) Tindakan konsiten masing-masing guru perlu berdayakan antara lain : a) Perlu diupayakan kinerja tepat waktu, b) kedisiplinan dan ketelitian guru dalam pengelolaan administrasi kelas, dan c) kelengkapan administrasi lain harus berdasar pada nilai fungsi.

2) Pada saat supervisi : a) Kepala Sekolah sebaiknya terprogram secara rinci instrument-instrumennya, agar kelngkapan dan pengelolaan administrasi kelas masing-masing guru dapat diukur kesiapannya, c) kerja sama kemimitraan antar guru harus ditumbuhkembangkan maksimal utamanya pada pembahasan administrasi kelas.

3) Pada saat kegiatan rapat dinas secara rutin hendaknya pada buku penghubung disertakan pokok-pokok masalah yang akan dibahas dengan orientasi dasar administrasi kelas.

4) Pada saat supervisi hendaknya tidak mencari-cari kesalahan guru, sebaliknya harus ditumbuhkan semangat kinerja dan kesadaran guru dalam memahami tugasnya.

\section{Siklus 2}

Dengan melihat hasil rekomendaqsi pada siklus pertama, penulis telah melakukan penyempurnaan pada siklus kedua dengan hasil-hasil berupa kemampuan guru dalam melakukan pengelolaan administrasi kelas melalui data aktivitas kinerja yang menunjukkan peningkatan kemampuan guru pada pengelolaan administrasi kelas pada siklus ke dua melalui tindakan supervisi kepala sekolah pertama hasilnya 77,44.

Dari data prosentase ketujuh guru di atas terlihat adanya hasil supervisi secara kualitatif dengan klasifikasi yang mencapai kategori sangat baik 2 guru, mencapai baik 2 guru, mencapai cukup 3 guru, mencapai kurang 0 guru, dan mencapai sangat kurang 0 guru. Berdasarkan data tersebut dapat disimpulkan bahwa kemampuan guru dalam mengelola administrasi kelas jika mencapai maksimal (sangat baik) akan memperoleh skor 700 dari 7 (tujuh) orang guru. Sementara hasil penelitian pada tindakan pertama kegiatan supervisi kelas baru mencapai rata-rata 77,14 persen atau tingkat keberhasilannya masih jauh dibawah $75 \%$, hal ini menunjukkan para guru SDN Badurame I, kecamatan Turi kemampuannya mencapai pada kategori baik.

Pada tahap berikutnya kepala sekolah mengajak para guru untuk berupaya meningkatkan kelengkapan dan pengelolaan administrasi kelas yang lebih baik.

Guru yang merasa tugasnya masih kurang sempurna harus menyempurnakan hingga mencapai hasil maksimal. Hal ini 
dimaksudkan agar pelaksanaan kegiatan pembelajaran berjalan normal dan masing-masing guru akan memiliki kompetensi padabidangnya secara professional. Sebaliknya jika kekurangan itu tidak segera diperbaiki akan berdampak ini pada kegiatan-kegiatan selanjutnya.

Berikut ini data kinerja guru yang menunjukkan kemampuan mengelola administrasi kelas pada siklus ke dua tindakan supervisi kedua saat pembahasan pembuatan administrasi kelas, hasilnya 80 .

Dari data tersebut di atas menunjukkan adanya perubahan dari data skor awal tercatat 57,14 atau 57 persen, pada tindakan supervisi pertama siklus ke dua skor tercatat 77,14 atau 77 persen, pada skor tindakan supervisi ke dua menjadi 80 atau 80 persen. Hal ini dapat disimpulkan bahwa frekuensi supervisi harus berlangsung secara inten dan terprogram guna upaya peningkatan kemampuan guru dalam mengelola administrasinya semakin baik dan sempurna.

Pada akhir tahap ini kepala sekolah memberikan penilaian mengenai hasil kinerja guru. Hal ini dimaksudkan untuk lebih memberikan semangat kepada guru bahwa semakin sempurna dan teliti dalam mengerjakan administrasi kelas akan mendapat penghargaan (nilai) yang lebih baik pada DP3-nya.

Pada akhir kegiatan, kepala sekolah dan guru berdiskusi berdasar pada beberapa kesimpulan kegiatan dan memberikan alternative guna peningkatan kemampuan pengelolaan administrasi kelas selanjutnya. Sebelum kegiatan supervisi lanjutanberlangsung kepala sekolah juga memberikan tugas agar guru mempelajari pedoman pengelolaan administrasi berikut penerapan di kelas masing-masing guru.

\section{Hasil Tindakan Supervisi pada Siklus Ke Dua}

Berdasarkan hasil tindakan supervisi yang telah dilaksanakan dua kali terhadap masing-masing guru menunjukkan bahwa telah ada peningkatan kemampuan guru dalam pengelolaan administrasi kelas.

Dari 7 (tujuh) guru telah menunjukkan kemampuannya dalam mengelola administrasi kelas masing-masing. Selama dilakukannya pembinaan dan tindakan supervisi kelas masing-masing guru kelas dua kali oleh kepala sekolah hasilnya dapat diketahui pada tabel berikut:

Tabel 3: Hasil Penelitian Dua Kali Supervisi pada Siklus Kedua

\begin{tabular}{|c|c|c|c|c|c|c|}
\hline \multirow[t]{2}{*}{ No } & \multirow{2}{*}{$\begin{array}{l}\text { Aspek } \\
\text { Yang } \\
\text { dinilai }\end{array}$} & \multicolumn{5}{|c|}{ Skor } \\
\hline & & $\begin{array}{c}\text { Awal } \\
(0)\end{array}$ & $\begin{array}{l}\text { Supervisi } \\
\text { (I) }\end{array}$ & $\begin{array}{l}\text { Supervisi } \\
\text { (2) }\end{array}$ & $\begin{array}{c}\text { Jumlah } \\
(+)\end{array}$ & Peningkatan \\
\hline 1 & 1 & 00 & 200 & 200 & 400 & Nihil \\
\hline 2 & 2 & 160 & 160 & 240 & 560 & +80 \\
\hline 3 & 3 & 120 & 180 & 120 & 420 & Nihil \\
\hline 4 & 4 & 120 & 00 & 00 & 120 & -40 \\
\hline 5 & 5 & 00 & 00 & 00 & 00 & Nihil \\
\hline- & Jumlah & 400 & 540 & 560 & 1.500 & - \\
\hline- & Rata-rata & 57,14 & 77,14 & 80 & - & - \\
\hline
\end{tabular}


Berawal dari data tersebut para guru diberikan pembinaan oleh kepala sekolah dan dilakukan pengawasan secara intensif oleh kepala sekolah.Secara bertahap kepala sekolah melakukan supervisi melalui siklus-siklus. Siklus ke dua dilakukan 2 (dua) kali supervisi, tindakan pertama diperoleh data rata-rata skor guru 77,14 atau 77 persen, selanjutnya pada tindakan supervisi ke dua diperoleh skor rata-rata 80 atau 80 persen. Skor tersebut jika dibandingkan dengan skor sebelumnya terdapat peningkatan 2,86 atau 3 persen.

Kemudian pada tahap ke dua diperoleh data berupa skor rata-rata beserta persentasenya.Dengan demikian pelaksanaan tindakan penelitian ini mempunyai dampak positif terhadap peningkatan kemampuan guru mengelola administrasi kelas, dan perlu pengembangan lebih lanjut dan penyempurnaan yang berarti.

\section{Rekomendasi Siklus Kedua}

Dengan memperhatikan hasil siklus kedua,penulis membuat refleksi perbaikan pelaksanaan kegiatan pembelajaran pada siklus kedua ini sbb:

Walaupun pada siklus ke dua ini hasil belum menunjukkan perubahan signifikan, tetapi ada beberapa catatan penyempurnaan yang masih perlu dilakukan, antara lain:

1. Tindakan konsiten masing-masing guru perlu berdayakan antara lain : a) Perlu diupayakan kinerja tepat waktu, b) kedisiplinan dan ketelitian guru dalam pengelolaan administrasi kelas, dan c) kelengkapan administrasi lain harus berdasar pada nilai fungsi.

2. Pada saat supervisi : a) Kepala Sekolah sebaiknya terprogram secara rinci instrument-instrumennya, agar kelngkapan dan pengelolaan administrasi kelas masing-masing guru dapat diukur kesiapannya, c) kerja sama kemimitraan antar guru harus ditumbuhkembangkan

maksimal

utamanya pada pembahasan administrasi kelas.

3. Pada saat kegiatan rapat dinas / rutin hendaknya pada buku penghubung disertakan pokok-pokok masalah yang akan dibahas dengan orientasi dasar administrasi kelas.

4. Pada saat supervisi hendaknya tidak mencari-cari kesalahan guru, sebaliknya harus ditumbuhkan semangat kinerja dan kesadaran guru dalam memahami tugasnya.

\section{Siklus 3}

Dengan melihat hasil rekomendaqsi pada siklus ke dua, peneliti telah melakukan penyempurnaan pada siklus ke tiga dengan hasil-hasil berikut ini mengenai kemampuan guru dalam melakukan pengelolaan administrasi kelas melalui data aktivitas kinerja yang menunjukkan peningkatan kemampuan guru pada pengelolaan administrasi kelas pada siklus pertama melalui tindakan supervisi kepala sekolah pertama hasilnya 85,71 .

Dari data prosentase ke delapan guru di atas menunjukkan adanya hasil supervisi secara kualitatif dengan klasifikasi yang mencapai kategori sangat baik 3 guru, mencapai baik 3 guru, mencapai cukup 1 guru, mencapai kurang 0 guru, dan mencapai sangat kurang 0 guru. Berdasarkan data tersebut dapat disimpulkan bahwa kemampuan guru dalam mengelola administrasi kelas jika mencapai maksimal ( sangat baik) akan memperoleh skor 700 dari 7 (tujuh) orang guru. Sementara hasil penelitian pada tindakan pertama kegiatan supervisi kelas mencapai rata-rata 85,71 persen atau tingkat keberhasilannya berada di atas rata-rata $75 \%$, hal ini menunjukkan para guru SDN Badurame I, kecamatan Turi mencapai tingkat kemampuan melakukan kegiatan pengelolaan administrasi kelas pada kategori baik. 
Pada tahap berikutnya kepala sekolah mengajak para guru untuk berupaya meningkatkan kelengkapan dan pengelolaan administrasi kelas yang lebih baik.Guru yang merasa tugasnya masih kurang sempurna harus menyempurnakan hingga mencapai hasil maksimal. Hal ini dimaksudkan agar pelaksanaan kegiatan pembelajaran berjalan normal dan masing-masing guru akan memiliki kompetensi pada bidangnya secara professional. Sebaliknya jika kekurangan itu tidak segera diperbaiki akan berdampak ini pada kegiatan-kegiatan selanjutnya.

Data kinerja guru yang menunjukkan kemampuan mengelola administrasi kelas pada siklus ketiga tindakan supervisi kedua saat pembahasan pembuatan administrasi kelas, hasilnya 85,71.

Dari data tersebut di atas menunjukkan adanya perubahan dari data skor awal tercatat 57,14 persen, pada tindakan supervisi pertama tercatat 85,71 persen, pada skor tindakan supervisi ke dua menjadi 91,42 persen. Hal ini dapat disimpulkan bahwa frekuensi supervisi harus berlangsung secara inten dan terprogram guna upaya peningkatan kemampuan guru dalam mengelola administrasinya semakin baik dan sempurna.

Pada akhir tahap ini kepala sekolah memberikan penilaian mengenai hasil kinerja guru. Hal ini dimaksudkan untuk lebih memberikan semangat kepada guru bahwa semakin sempurna dan teliti dalam mengerjakan administrasi kelas akan mendapat penghargaan (nilai) yang lebih baik pada DP3-nya.

Pada akhir kegiatan, kepala sekolah dan guru berdiskusi berdasar pada beberapa kesimpulan kegiatan dan memberikan alternative guna peningkatan kemampuan pengelolaan administrasi kelas selanjutnya. Sebelum kegiatan supervisi lanjutan berlangsung kepala sekolah juga memberikan tugas agar guru mempelajari pedoman pengelolaan administrasi berikut penerapan di kelas masing-masing guru.

\section{Hasil Tindakan Supervisi pada Siklus Ketiga}

Berdasarkan hasil tindakan supervisi yang telah dilaksanakan dua kali terhadap masing-masing guru menunjukkan bahwa telah ada peningkatan kemampuan guru dalam pengelolaan administrasi kelas.

Dari 7 (tujuh) guru telah menunjukkan kemampuannya dalam mengelola administrasi kelas masing-masing. Selama dilakukannya pembinaan dan tindakan supervisi kelas masing-masing guru kelas dua kali oleh kepala sekolah hasilnya dapat diketahui pada tabel berikut:

Tabel 4: Hasil Penelitian Dua Kali Supervisi pada Siklus Ke Tiga

\begin{tabular}{|c|c|c|c|c|c|c|}
\hline \multirow{2}{*}{ No } & \multirow{2}{*}{\begin{tabular}{c} 
Aspek \\
Yang \\
\cline { 3 - 7 }
\end{tabular}} & \multicolumn{5}{|c|}{ Skor } \\
\cline { 3 - 7 } & 1 & Awilai & Supervisi I & Supervisi 2 & Jumlah & Peningkatan \\
\hline 1 & 1 & 00 & 300 & 400 & 700 & Nihil \\
\hline 2 & 2 & 00 & 240 & 240 & 480 & +80 \\
\hline 3 & 3 & 240 & 60 & 00 & 300 & Nihil \\
\hline 4 & 4 & 80 & 00 & 00 & 80 & -40 \\
\hline 5 & 5 & 40 & 00 & 00 & 40 & Nihil \\
\hline- & Jumlah & 360 & 600 & 640 & 1600 & - \\
\hline- & Rata-rata & 45 & 85,71 & 91,42 & - & - \\
\hline
\end{tabular}

Berdasarkan data di atas dapat dujelaskan bahwa dari 7 (tujuh) guru kelas sebelum dilakukan penelitian tindakan berupa supervisi kelas diperoleh 
data kemampuan guru dalam mengelola administrasi kelas skor rata-rata menunjukkan angka 57,14 atau 57 persen.

Berawal dari data tersebut para guru diberikan pembinaan oleh kepala sekolah dan dilakukan pengawasan secara intensif oleh kepala sekolah. Secara bertahap kepala sekolah melakukan supervisi melalui siklussiklus. Siklus ke Tiga dilakukan 2 (dua) kali supervisi, tindakan pertama diperoleh data rata-rata skor guru 85,71 atau 86 persen. Skor tersebut jika dibandingkan dengan skor sebelumnya terdapat peningkatan atau persen.

Kemudian pada tahap ke dua diperoleh data berupa skor rata-rata 91,42 atau 91 persen. Dengan demikian pelaksanaan tindakan penelitian ini mempunyai dampak positif terhadap peningkatan kemampuan guru mengelola administrasi kelas, dan perlu pengembangan lebih lebih lanjut dengan penyempurnaan yang berarti.

\section{Rekomendasi Siklus Ketiga}

Dengan memperhatikan siklus ketiga ini penulis memberikan rekomendasi bahwa upaya peningkatan kemampuan guru mengelola administrasi kelas melalui supervisi kelas adalah sangat baik dan berdampak positif.

\section{Pembahasan Peningkatan Kemampuan Guru Mengelola Administrasi Kelas}

Peningkatan kemampuan guru mengelola administrasi kelas dari dua tindakan supervisi masing-masing siklus.

Berdasarkan data-data dari hasil penelitian tindakan pada tindakan awal , siklus I (tindakan 1-2), Siklus II (tindakan 1-2) dan Siklus III (tindakan 1-2) dapat dirangkum guna diketahui ada tidaknya peningkatan kemampuan guru dalam mengelola administrasi kelas, sebagai berikut:

Tabel 5: Rekapitulasi Peningkatan Kemampuan Guru Mengelola Administrasi Kelas

\begin{tabular}{|c|c|c|c|c|c|c|c|c|}
\hline \multirow[b]{2}{*}{ No } & \multirow{2}{*}{$\begin{array}{c}\text { No } \\
\text { Aspek } \\
\text { yg } \\
\text { dinilai }\end{array}$} & \multirow[b]{2}{*}{$\begin{array}{l}\text { Skor } \\
\text { Awal }\end{array}$} & \multicolumn{2}{|c|}{ Siklus I } & \multicolumn{2}{|c|}{ Siklus II } & \multicolumn{2}{|c|}{ Siklus III } \\
\hline & & & 1 & 2 & 1 & 2 & 1 & 2 \\
\hline 1 & 1 & 00 & 100 & 100 & 200 & 200 & 300 & 400 \\
\hline 2 & 2 & 160 & 160 & 240 & 160 & 240 & 240 & 240 \\
\hline 3 & 3 & 120 & 180 & 120 & 180 & 120 & 60 & 00 \\
\hline 4 & 4 & 120 & 40 & 40 & 00 & 00 & 00 & 00 \\
\hline 5 & 5 & 00 & 00 & 00 & 00 & 00 & 00 & 00 \\
\hline \multicolumn{2}{|c|}{ Jumlah } & 400 & 480 & 500 & 540 & 560 & 600 & 640 \\
\hline \multicolumn{2}{|c|}{ Rata-rata } & 57,14 & 68,57 & 71,42 & 77,14 & 80 & 85,71 & $\begin{array}{c}91,4 \\
2\end{array}$ \\
\hline
\end{tabular}

\footnotetext{
Keterangan :

$75 \%=$ Meningkat

$<75 \%=$ tidak meningkat
}

Dari data di atas telah secara jelas tergambar bahwa terdapat peningkatan kemampuan guru dalam mengelola administrasi kelas melalui supervisi kepala sekolah dari skor awal sebesar 57,14 dengan masing-masing siklus dilakukan supervisi sebanyak 2 (dua) kali maka diperoleh skor rata-rata pada siklus I sebesar 68,57 dan 71,42, siklus II sebesar 77,14 dan 80,00, dan Siklus III menjadi 85,71 dan 91,42. 


\section{Peningkatan Kemampuan Guru Mengelola Administrasi Kelas}

Untuk mengetahui peningkatan

kemampuan guru mengelola administrasi kelas, diperoleh hasil dari masing-masing siklus sebagai berikut. dirangkum dalam table berikut:

Tabel 6: Hasil Peningkatan Kemampuan Guru Mengelola Admin
\begin{tabular}{|c|l|c|}
\hline No & \multicolumn{1}{|c|}{ Skor masing-masing Siklus } & Nilai rata-rata \\
\hline 1 & $\begin{array}{l}\text { Siklus I } \\
\text { a. Tindakan } 1=68,57 \\
\text { b. Tindakan 2 }=71,42\end{array}$ & $\mathbf{6 9 , 9 9}$ \\
\hline 2 & $\begin{array}{l}\text { Siklus II } \\
\text { a. Tindakan } 1=77,14 \\
\text { b. Tindakan 2 } 80,00\end{array}$ & $\mathbf{7 8 , 5 7}$ \\
\hline 3 & $\begin{array}{l}\text { Siklus III } \\
\text { a. Tindakan } 1=85,71 \\
\text { b. Tindakan 2 }=91,42\end{array}$ \\
\hline
\end{tabular}

Dari data di atas setelah dikomulatifkan menunjukkan skor ratarata dari masing-masing siklusnya dan dapat disimpulkan bahwa dari siklus ke siklus telah terjadi peningkatan kemampuan guru mengelola administrasi kelas, yaitu pada siklus pertama nilai rata-rata komulatif 69,99 pada siklus kedua meningkat menjadi 78,57 dan pada siklus ketiga menjadi 88,56.

Berdasarkan data-data di atas dapat disimpulkan bahwa melalui kegiatan supervisi kepala sekolah terjadi peningkatan kemampuan guru mengelola administrasi kelas. Hal ini dapat diartikan bahwa rumusan hipotesis tindakan yang dikemukakan pada penilitian ini adalah benar.

\section{SIMPULAN}

Berdasarkan data hasil penelitian dan pembahasan pada bab-bab sebelumnya dapat dikemukakan beberapa simpulan sebagai berikut :

a. Kegiatan supervisi kelas dapat meningkatkan kemampuan guru mengelola administrasi kelas di Sekolah Dasar Negeri Badurame I, kecamatan Turi.

b. Kegiatan supervisi secara terprogram dapat meningkatkan kemampuan guru mengelola administrasi kelas di
Sekolah Dasar Negeri Badurame I, kecamatan Turi.

\section{DAFTAR RUJUKAN}

Depdiknas, 2000, Petunjuk Pelaksanaan Supervisi di Sekolah, Jakarta

Depdikbud.1994, Pedoman Bimbingan Guru dalam Proses Belajar Mengajar. Jakarta:Direktorat Guru dan Tenaga Teknis Departemen Pendidikan dan Kebudayaan.

De Porter,B.M.Reandon. S. Sarah and Nourle.2000. Quantum Teaching. Bandung :Kaifa.

Djauzak, dan A.1994.Petunjuk Peningkatan Mutu Pendidikan di Sekolah dasar. Jakarta. Direktorat Pendidikan Dasar Departemen Pendidikan dan kebudayaan.

Panjaitan, Binsar. 1997. Pengaruh Interaktif antara Pemberian Balikan dan Motivasi Berprestsi terhadap Perolehan Belajar. Journal Teknologi Pembelajaran IPTP dan Pascasarjana TEP IKIP Malang. 
Porter, B. and M.Hernacki.2000. Quantum Learning. Bandung:kaifa.

Sayekti, Y.1986. Evaluasi Hasil Belajar IPA. FPIPS. Malang.

Wibawa. Basuki. 2001. Penelitian Tindakan Kelas. Ditjen Tenaga Kependidikan. Dirjen Dikdasmen Depdiknas.Jakarta.
Wiriatmadj, Rochiati,2006. Metode Penelitian Tindakan Kelas, Bandung, Remaja Rosdakarya.

Witjaksono,M. dan Soewandi.1982. Strategi Belajar Mengajar.Malang: Bursa Pendidikan Bisnis FPIPS IKIP Malang.

Yaudianto,1997. Kamus Umum bahasa Indonesia. Bandung : M2S. 